\title{
AD HOC ALLIANCES AS ITALIAN KEY STATECRAFT TOOL
}

\author{
MARIA SHIBKOVA \\ MGIMO University, Moscow, 119454, Russia
}

\begin{abstract}
Despite economic troubles and constant political instability, Italy manages to retain its historical role as a key EU state and one of the three major economies of the region, which justifies its G7 membership and therefore formally endues it with a great power status. This is due to accommodationism having been the main behavioral pattern since the establishment of the Italian Republic, and the skillful use of $a d$ hoc alliances - a pragmatic statecraft tool which renders Italy flexible and unpredictable. Too big to be defensive, but too small to be offensive, Italy does not provoke antagonism in any EU country, potentially becoming a universal ally. Cooperation with Greece on fiscal flexibility, with Spain and France on Corona bonds, and with Hungary on EU common migration policy strengthens its bargaining power in the EU, since the latter needs Italy for reasons of security and solidarity. Having furthermore been a devoted US partner since the end of World War II, Italy considers the United States a guarantor of its national security and position on the international arena and is inclined to lend its support to Washington even if such actions contradict the policies of closer geostrategic partners in the EU. Thanks to such an allegiance Italy manages to preserve a certain room for maneuvering in interactions with other nonEuro-Atlantic partners to an extent that does not imperil its strategic alliance with Washington, which has always been an invariable of Italian foreign policy. However, scarce attention from the USA under the Trump administration made Italy utilize its statecraft tools towards Washington as well, and a pragmatic rapprochement with China on the Belt and Road Initiative and humanitarian aid during the pandemic presents a clear example thereof.
\end{abstract}

Keywords:

Italian foreign policy; statecraft; coronavirus; coronavirus crisis; Italy-Russia relations; Italy-EU relations; Italy-US relations; Italy-China relations.

The term statecraft, although it is widely used in foreign works on political science, has not yet received a generally accepted equivalent in Russian. One of the textbook definitions was given by Professor Kalevi Holsti from the University of British Columbia:
"Organized actions governments take to change the external environment in general or the policies and actions of other states in particular to achieve the objectives that have been set by policy makers" [Holsti 1976: 293]. Russian researcher Mikhail Troitskiy inter-

This article is a result of a collaborative research project on the modern trends in the evolution of statecraft by the MGIMO School of Government and International Affairs and the Sam Nunn School of International Affairs at the Georgia Institute of Technology. A Russian version of this article is published in the second part of this special issue of International Trends. The Russian and English versions are not identical. The key term statecraft cannot be translated directly into Russian, that is why the Russian articles in this special issue use a variety of longer definitions of statecraft depending on the context. For a discussion of English and Russian definitions see the introductory article in this volume.

Manuscript received: 30.09.2020

Manuscript accepted: 29.03.2021

Corresponding author:

Email: m.shibkova@inno.mgimo.ru 
prets statecraft as "a set of behavioral patterns used to achieve measurable results" [Jordan et al. 2021a; 2021b]. The most appropriate interpretation of statecraft appears to be "a foreign policy toolkit". At the same time, the ways of conducting foreign policy "should demonstrate a clear connection between cause and effect and be replicable" [Jordan et al. 2021a; 2021b].

While analyzing a state's foreign policy tools, technologies and methods used in foreign policy in order to change the behavior of other players in accordance with the own interests of the state have been considered as examples thereof. As a rule, states are prone to stereotypical behavior and are guided by the same attitudes, formed - depending on the state's choice - on the tradeoff of ideology and pragmatism, readiness to seek compromise and demonstration of force, or alliance commitments and disposition to show flexibility and variability in the choice of coalitions. Accordingly, the study of foreign policy in terms of the application of certain tools and methods does not aim to analyze the intentions and ultimate goals of the state; it is the tools themselves and their combinations that matter. Therefore, the key research question is not "What does the state seek to achieve?" but "How does the state achieve what it wants?".

Russian researchers have traditionally focused on foreign policy analysis, to which significant contributions were made by A.D. Bogaturov, M.A. Khrustalev, T.A. Shakleina, A.A. Baykov, I.A. Istomin, and many others [Modern 2009; Khrustalev 2011; Introduction... 2014; Istomin 2018; Istomin, Baykov 2019]. At first glance, the subject fields of foreign policy analysis and foreign policy tools overlap; this makes it difficult to single out the latter as a separate branch of knowledge. Substantial similarities of these areas do occur; however, the study of foreign policy tools allows conceptualizing the state's behavior in the international context, tracing the evolution of its actions in the international arena, and compar- ing its tools with other states without affecting its goals and interests, unlike in the case of general foreign policy analysis.

The study of foreign policy tools also differs from the study of foreign policy strategy, since the latter implies the consideration of state actions to achieve a certain a priori known goal. Another related area is the analysis of foreign policy resources, but its practical applicability is limited by the fact that the presence of great potential in states does not automatically imply its full application, whereas a state with a relatively low foreign policy potential, on the contrary, may pose a threat to the entire world community. In other words, "strong" is not always identical to "dangerous," or "weak" to "harmless". The study of strictly foreign policy resources does not allow us to make predictions about the actual behavior of a state, because there is no direct correlation between the amount of resources and the willingness to use them. The study of behavioral patterns is, therefore, of great practical relevance, since their transformation, being noticeable at the proper depth of analysis, will signal a change in the goals, intentions, and, subsequently, the strategy of the state in the international arena, which would have only been guessed at in the absence of observations over the foreign policy tools.

\section{1}

In terms of foreign policy tools, Italy is not a trivial object of analysis. A member state of the Group of Seven, and one of the founding countries of the European Union, it ranks equally with the strongest powers in the global context, despite the absence of nuclear weapons and global ambitions, a fairly modest defense budget ${ }^{1}$, a non-aggressive foreign policy (in the postwar period), structural economic problems, and an unstable domestic political situation. Italy has positioned itself as "the smallest among the big ones and the biggest among the small ones". At the same time, participation in the Group of Seven suggests the

${ }^{1}$ On average, 1.5\% of GDP over the past 20 years according to SIPRI. URL: https://www.sipri.org/ sites/default/files/Data\%2Ofor\%20all\%20countries\%20from\%201988-2019\%20as\%20a\%20 share\%20of\%20GDP.pdf (accessed: 14.09.2020). 
possibility of granting the country a great power status as well. It is obvious that such an image has been formed as a result of the effective and sustainable foreign policy tools, having nothing to do with the methods of hard power, which are considered an integral part of any state's strength and influence in international affairs.

Speaking of the Italian perception of foreign policy goals and instruments, one cannot fail to mention the country's fascist past, from which it sought to move as far away as possible throughout the postwar period. After World War II, Italy - like Germany and Japan - underwent major changes in its foreign policy strategy: after the heavy defeat suffered by the country's ideology and the widespread global understanding that the war was not worth the large-scale political, economic, and human losses incurred, the power in Italy was taken by the new politicians who advocated the principles of rejecting the use of force as a foreign policy tool and preventing military conflicts. In the postwar period, Italy's foreign policy was built from the perspective of a «middle power» [Nuti 2011], which meant mainly moving away from the global ambitions of the past, adhering to democratic norms, and protecting its economic interests. Having chosen the United States as its main ally and participation in European integration as the main path of development within the Western bloc, Italy staked on a "strategy of international re-legitimization" [Diodato, Niglia 2017], designed to help the country restore its status as a responsible actor in international relations, behaving exclusively within the legal framework.

Throughout the Cold War, Italian foreign policy remained relatively passive in order to avoid incitement of further divisions within the Italian society already split into Communists and Christian Democrats. In a number of areas (e.g., the Mediterranean), Rome nevertheless took the initiative, defending its interests that did not go beyond its alliance with the United States. The very logic of the international situation at that time - the confrontation of the two superpowers - left no room on the "stage" for other states. In this sense, Italy, having entrusted its national security to the North
Atlantic Treaty Organization (NATO), did not challenge decisions of the U.S. administration, remaining a loyal but inactive partner within the NATO framework. Professor Paolo Rosa of the University of Trento called Italy during the Cold War 'an accommodationist state' (Rosa, 2014), describing in this term Rome's consistent but passive support of its main ally and security guarantor (Washington), while unwilling to build up its own military power and take international initiatives involving the use of force, preferring instead to entrust the resolution of armed conflicts to international organizations. This term could be translated into Russian as "opportunism," but this has a distinctly negative connotation, although it reflects to some extent the political pragmatism inherent to Italy in the context of relations with the United States. Accomodationism as a model of foreign policy behavior was not indicative of isolationism: in the postwar period, Italy was part of UN missions in Somalia, Egypt, Lebanon, the Democratic Republic of the Congo, and Laos.

If the passive foreign policy strategy in the period of the bipolar confrontation was logical and prompted by the objective need for a clear choice of bloc, in the post-bipolar world the situation has changed significantly. It should be noted that the Italians are traditionally much more concerned about their domestic politics than about events beyond the national borders, due to the Italian mentality, which is reflected in exclusive preoccupation with their family, small business, hometown, etc. This fact is reflected both on the domestic level - in any newspaper, the "politics" section of the news will be about the situation in Italy rather than abroad - and on the political level - electoral platforms of the parties are almost entirely devoted to the domestic policies, while the foreign policy is at most sketched at the end.

Nevertheless, the Italian authorities are fully aware of the extent to which their domestic policy depends on changes in the external environment. The birth of the Italian Republic coincided with the beginning of the Cold War, the logic of which determined all the subsequent years of the state's existence. With the end of bipolar division, Italy was reborn and 
began a new chapter in history under the name of the Second Republic; accommodationism nevertheless remained the main characteristic of its foreign policy. From a devastated and economically backward country, Italy has developed into one of the world's leading powers, a member of the Group of Seven, and one of the ten strongest economies in the world (in 2019, it ranked eighth by GDP volume) ${ }^{2}$. The country's foreign policy has a strong pacifist component; the use of force is seen as possible only with a mandate from international organizations, where Italy demonstrates active participation. Since 1991, the country has participated in 30 missions in Africa, Asia, and Europe, and currently there are ten missions under the aegis of the UN, the EU, and $\mathrm{NATO}^{3}$ that are in an active phase. At the same time, Rome continues to demonstrate its loyalty to Washington, considering it its main ally and guarantor of security.

Relations with the United States occupy a special place in the Italian system of coordinates; for Rome, in exchange for its loyalty, the great power status of this overseas partner serves as a pillar of support and a guarantee of a stable position in the international arena. Italians, unlike many of their European neighbors for whom cooperation within the EU is an integral part of a broader concept of Western partnership with the leading role of the United States, traditionally draw a distinction between the concepts of Europeanism and Atlanticism. Alternation of these two key foreign policy priorities takes place depending on the political views of a particular cabinet of ministers: the center-right historically gravitated toward Washington and the center-left toward Brussels [Maslova 2016: 107]. Commitment to Atlantic solidarity did not always imply maintaining high loyalty within the European bloc and, on the other hand, tensions within the EU did not affect Italian-American relations.

Osvaldo Croci, professor at Memorial University of Newfoundland, distinguishes two approaches to the correlation of the concepts of Europeanism and Atlanticism: they are either seen as mutually exclusive and opposing phenomena, or as a 'nested game'4. According to its rules, Europeanism is a part of Atlanticism, which is "traditionally considered by the Italian leadership as a policy aimed at strengthening Atlanticism" [Croci 2008: 139]. Loyalty to the Atlantic bloc remains a key foreign policy stance for Italy for at least two reasons: firstly, Italy perceives NATO membership as the cornerstone of its security due to its vulnerable geopolitical position on the external borders of the alliance; secondly, close friendly relations with the United States guarantee Italy a place among the four (only three after Brexit) EU policymakers, as well as the prestigious title of one of the members of the closed Group of Seven.

More importantly, Euroscepticism, popular in Italy in recent years, is rooted in the turn toward Atlanticism during Silvio Berlusconi's first and second governments and the more active development of this trend (compared to Europeanism) during his third and fourth governments. The pendulum of center-right foreign policy more often tilted toward strengthening ties with the United States, which led to a decrease in the intensity of cooperation with European partners. One of the members of NATO most loyal to Washington, Italy was the first member of the alliance to deploy Jupiter intermediate-range ballistic missiles on its territory in 1959; in 1979, the Italian parliament approved the deployment of Pershing-2 intermediate range ballistic missiles, and later the government agreed to deploy cruise missiles; in 1999, Italy played a key role in providing the logistical component of the NATO intervention in Kosovo, providing allied forces with its air-

\footnotetext{
${ }^{2}$ World Bank Statistics. URL: https://data.worldbank.org/indicator/NY.GDP.MKTP.CD. Caccessed: 11.09.2020).

${ }^{3}$ Operazioni Internazionali. Ministero della Difesa. URL: http://www.esercito.difesa.it/operazioni/ operazioni oltremare/Pagine/default.aspx (accessed: 11.09.2020).

4 The term 'nested game' was coined by George Tsebelis (Nested Games. Rational Choice in Comparative Politics, 1990) to refer to the intertwining and embedding of one concept into another.
} 
fields. Rome's unequivocal support of Washington during the periods of center-right government also led to explicit condemnation by leading European countries. For example, Italy participated in military operations in Iraq (despite German and French criticism) and in Libya (notwithstanding the ambivalent position of Berlin).

By consistently proving its loyalty to the principles of Atlantic solidarity, Italy has earned "room for maneuver" [Croci 2015: 51]: that is, the opportunity to act independently in matters that are not of key importance to the United States, but are sensitive to Italy. Since 2014, Rome has demonstrated the same approach with regard to anti-Russian sanctions: it defended its own interests and pursued an independent policy line as long as this did not jeopardize relations with the United States.

The pursuit of national interests in areas that are not strategically important to the United States and by means that do not call into question Rome's pro-Atlantic orientation is not a $21^{\text {st }}$ century novelty. The first outcomes of such policy date back to the postwar period and can be illustrated by the example of ItalianSoviet relations.

In the Cold War era, contacts between countries from different blocs were highly undesirable because they touched on the subject of loyalty, a matter sensitive for both superpowers. Nevertheless, in the late 1950s and early 1960s, Italy adopted the policy of neo-Atlanticism, which involved "developing a privileged partnership with the United States while secretly striving for hegemony in the Mediterranean" [Manta 2018: 208]; thus, it began to form a new international image of a mediator between East and West. This role was perfect for Italy because of its geostrategic position on the border of the Iron Curtain in the Mediterranean.

The new Italian policy involved the task of establishing contacts with countries that were not part of the capitalist bloc. According to the
Italian establishment, at the new stage of the Cold War, military deterrence was no longer sufficient, and "delicate capillary work was needed to devastate the Soviet power from within in order to weaken it and assert the superiority of the Western system" (Salacone, 2014: 112). In an effort to be a useful member of NATO and simultaneously defend its own interests, Italy went into rapprochement with the USSR, mainly using the tools of economic diplomacy, which had become available to it due to the rapid growth and transformation of the Italian economy.

Rome and Moscow were of mutual interest to each other: the "Italian economic miracle" looked like a worthy example to the USSR that was concerned about its industrial backwardness compared to the West; Soviet natural gas reserves attracted Italy, which was in search of new sources of energy for the growing domestic demand. Another powerful factor in the rapprochement between the two countries was the Italian Communist Party, the largest in Western Europe with about two million members. According to Alessandro Salacone, researcher from the University of Naples, "the presence of the Communist Party in Italy, as well as its ties with the CPSU, were crucial in shaping the Italian vector of the Soviet foreign policy" [Salacone 2013: 4]; this consequently served as a particular starting point for bilateral cooperation and a constant area of mutual attraction. It was Rome that was destined to open the Iron Curtain, and it took advantage of this opportunity.

In 1960, the Italian oil and gas company Eni signed a four-year contract with the USSR for the supply of 12 million tons of oil per year ${ }^{5}$, thus becoming the first non-Socialist importer of Soviet oil. Further cooperation with Moscow expanded. In 1969, after years of negotiations, Russia signed a twenty-year contract with Eni for the supply of six billion cubic meters of natural gas per year ${ }^{6}$ in exchange

${ }^{5}$ Sviazannie energiej. 40 let sotrudnichestva Gazproma i Eni po puti sledovania prirodnogo gaza. (Connected by energy. 40 years of cooperation between Gazprom and Eni along the natural gas route.) 2009. URL: https://www.eni.com/ru_RU/attachments/pdf/eni-gazprom-bassa.pdf C. 4. Caccessed: 15.04.2021).

6 lbid. P. 10. 
for pipes and equipment for the construction of gas pipelines. An important milestone in bilateral economic relations was the signing in 1966 of an agreement between the Italian Fiat Group and the Soviet "Avtopromimport" on the construction of the AvtoVAZ automobile plant in the city named after Palmiro Togliatti, the general secretary of the Italian Communist Party.

One of the leading Italian masterminds behind establishing economic ties with Moscow, chairman of the Fiat automobile group Vittorio Valletta, saw in the development of non-military production in the USSR the possibility of "the much-needed demobilization of the USSR's labor force and military industry to redirect resources to consumer goods production and economic consolidation" [Castronovo 1999: 1058]. Consequently, one can conclude that the development of cooperation with the USSR was also in NATO's interest, since the increase in the number of Soviet citizens employed in non-military industries and the redistribution of state resources from the defense-industrial complex, including through the establishment of relations between Rome and Moscow, contributed to the easing of tensions between the blocs, which were especially deep after the construction of the Berlin Wall and the Cuban Missile Crisis. Anyway, having established an energy dialogue with the USSR, Italy remained a faithful ally of the United States within NATO on the main foreign policy fronts, as evidenced, above all, by its clear commitment to the course of European integration. For its part, the United States could not afford to "throw around" allies and had to give Italy a certain "freedom of maneuver". Through this process, it was in the 1960s that "the foundations of Soviet-Italian relations were laid and the features that would distinguish their bilateral ties in the future were defined" [Salacone 2018: 140].

At the present stage, it appears that Moscow, rather than Rome, attaches somewhat greater importance to the Russian-Italian political relations. The friendly nature of bilateral ties in the 21 st century cannot be denied, but the peak of mutual interest was reached during the pre- miership of Silvio Berlusconi, known for his personal friendship with Russian President Vladimir Putin. With the onset of EU sanctions against Russia in 2014, Moscow began to see Rome as a savior and apparent 'rebel' capable of breaking the vicious circle of constantly renewed mutual economic restrictions with its voice in the European Council. These expectations were particularly heightened after the entry of the League party into the ruling coalition in 2018, whose secretary Matteo Salvini "repeatedly publicly expressed sympathy for the Russian President" [Shibkova, Maslova, Loreto 2019: 151].

Despite uneasy relations with Brussels over the migration agenda, fiscal discipline issues, and, more recently, issues of European solidarity in connection with the fight against the coronavirus, Rome is adhering to the EU's common line on the sanctions issue. The explanation for this stance is again the priority relationship with the United States: RussianItalian relations are beyond the freedom of maneuver granted to Rome by Washington. In this context, the pro-Russian sympathies, expressed by Italian parties at various intensity, were destined to remain mere rhetoric, since the same League, having moved from opposition to the ruling coalition, did not influence Italy's vote on the approval of anti-Russian sanctions in the EU institutions.

Italian Eurosceptic parties - positioning themselves as opponents to the unfair EU policy toward Russia, the dominant power of Brussels, and the infringement of Italian national interests in this regard - were forced to choose between Moscow and Washington on the sensitive issue of anti-Russian sanctions. Given the traditional importance of Atlanticism for the center-right, namely the League and Forza Italia parties, there is no reason to argue that the choice could have been made in favor of Russia. The main Atlanticist Silvio Berlusconi, alongside his party in the European Parliament, tries to stick to neutrality, which, in particular, was reflected in his reaction to the American bombing of Syria in April 2018 that took place against the background of acute tensions in US-Russia relations. The politician offered to 
play the role of mediator in the establishment of dialogue between Moscow, Brussels, and Washington, while stressing the unconditional alliance with the United States ${ }^{7}$.

Matteo Salvini's words about 'madness'8 were associated with substantial criticism of U.S. actions because, in his words, "the examples of Afghanistan, Iraq and Libya have not taught the Americans anything"9. In fact, however, he gave no reason to doubt his Atlantic solidarity. The League's election campaign "Italians First" slogan resonated with the "America First" campaign slogan of Donald Trump, and the U.S. president himself made an impression on Salvini, as the latter stated during their meeting in Philadelphia in April 2016 before the preliminary election. Salvini's foreign policy adviser, Guglielmo Picchi, once claimed that the Atlantic orientation of the party remained unshaken, despite some isolated instances of divergence of opinion. According to Picchi, apart from the leader of the League, other politicians, such as Angela Merkel, criticized the U.S. actions in Syria, but "no one questions her Atlanticism"10. Picchi's words are confirmed by the fact that the first foreign representative that Salvini met with after the election results were announced was Lewis Eisenberg, the U.S. Ambassador in Rome.

Therefore, it seems evident that the Atlantic solidarity is at the core of the Italian foreign policy, and departure from it, including in the form of "flirting" with Russia, indicates nothing more than autonomy within the limits that do not jeopardize the allied relationship with the United States.
If strategic relations with the United States remain a perpetual principle of Italy's foreign policy, Rome's interactions with its EU partners and with Brussels are characterized by a sequence of alternating ups and downs. As one of the founding countries of the European Union, Italy was one of the most loyal Eurooptimists until the end of the Cold War. Since the mid-1990s, the Cabinet of Ministers led by Silvio Berlusconi ${ }^{11}$ brought the Atlantic direction of foreign policy to the forefront, to the detriment of the European one. Rome's relations with Brussels, Berlin, and Paris worsened in the context of the global financial and economic crisis; this situation developed into a crisis of eurozone sovereign debt, followed by EU demands for austerity, resulting in higher taxes and unemployment. Another factor that magnified Eurosceptic sentiments in Italy was the migration crisis, especially Brussels' decision on mandatory refugee quotas, which caused discontent among both citizens and political forces, who demanded that Brussels apply the principle of solidarity in practice.

It came as a surprise to Brussels that in 2018 the Eurosceptic coalition, whose both members had once campaigned against the EU and eurozone and harshly criticised EU institutions, came to power in Italy . Nevertheless, the need to maintain constructive relations with Rome, regardless of the political orientation of the cabinet left the European Commission, Berlin, and Paris no choice but to collaborate with the ruling coalition. At the first EU summit after the formation of the Italian cabinet, the new Prime Minister

\footnotetext{
${ }^{7}$ Berlusconi Mediatore: "Alleati degli USA ma Mosca non è Nemica. II Giornale. 16.04.2018. URL: http://www.ilgiornale.it/news/politica/berlusconi-mediatore-alleati-degli-usa-mosca-non-nemica1515764.html (accessed: 30.07.2020).

${ }^{8}$ Salvini-Berlusconi, l'Attacco in Siria Divide il Centrodestra. II Leghista a M5S e Forza Italia: «Basta Insulti». Corriere della Sera. 14.04.2018. URL: https://www.corriere.it/politica/18 aprile 14/attacco-

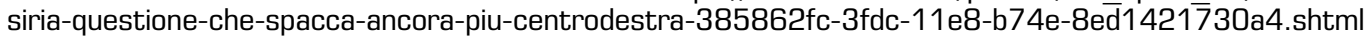
(accessed: 30.08.2020)

9 "Raketni siurpriz Donalda Trampa". Aviaudari SSHA vizvali protivorechivuji reaktsiju v mire. (Donald Trump's Missile Surprise. The U.S. airstrikes have provoked a controversial response in the world.) Izvestia. 07.04.2017. URL: https://iz.ru/news/678914ю. (accessed: 14.04.2021).

10 Lega Atlantista. II Foglio. 17.04.2020. URL: https://www.ilfoglio.it/politica/2018/04/17/news/legaatlantista-189757/. (accessed: 30.09.2020)

11 Silvio Berlusconi served as Prime Minister of Italy from 1994 to 1995, 2001 to 2005, 2005 to 2006, and 2008 to 2011.
} 
Giuseppe Conte managed to get concessions from member states on the migration agenda, the most sensitive issue for Rome. Conte agreed to a three-point compromise proposed by Emmanuel Macron: the establishment of camps for immigrants by EU countries on a voluntary basis, where refugee status would be confirmed or denied; the possibility of moving immigrants to a country other than the requested one (also on a voluntary basis); and enhanced protection of the EU external borders. It became possible to reach such a decision not because of the personality of the Italian prime minister, but because of an understanding in Brussels, Paris, and Berlin of the need to keep Italy within the European framework. Unity is especially needed in the face of pressing challenges, because of which the European Union "is increasingly exposed to accusations of excessive bureaucracy, technocratic domination, and deficit of democracy, which inevitably leads to a deepening gap between civil society and institutions of the European Union" [Zonova 2019: 64].

Italy seems to get away with its repeated violations of financial discipline and its demonstration of political autonomy (its e.g. participation in military operations in Iraq and Libya), as every time European partners seek to make concessions and prevent Rome's 'drift' toward Russia, the USA, or China. In such a way, Italy maintains its status as one of the three (post-Brexit) leaders of the European Union, making it reckon with Italy's opinion. This position has been achieved with the successful use of a specific instrument of foreign policy: ad hoc alliances; in this context, these are purely pragmatic situational alliances with less powerful EU countries, as well as with third countries, to 'bargain' concessions from Berlin, Paris, and Brussels. Having created an image of an unpredictable and sometimes flighty country, Italy has turned it into its strong point and a lever of pressure in relations with various partners.
Examples of the use of ad hoc alliances include the rapprochement with Greece in 2015 and support for the country's newly elected Prime Minister Alexis Tsipras. At the time, southern European countries with high levels of public debt to GDP and negative or zero economic growth were particularly exposed to the effects of austerity measures - recession and a spike in unemployment. The Greek Prime Minister chose a trip to Rome as one of his first official visits, during which Matteo Renzi, then Prime Minister and leader of the center-left coalition, expressed his intension to strengthen bilateral cooperation on all fronts. The Italian Minister of European Affairs stated that the election of Tsipras "presented new opportunities for changes in Europe that would promote growth, investment and the fight against unemployment"12. The desire for more flexible fiscal policies and relaxation of austerity has become a common interest between the two countries.

This rapprochement did not last long: on the eve of the Greek referendum in July 2015, Renzi came down on the side of German Chancellor Angela Merkel. The Italian prime minister urged Greece to abide by the established rules, the same for all, and not to "consider themselves the most cunning," because "the Italians did not reform the labor market so that some Greek ship-owners would continue not to pay taxes"13. For his part, Tsipras presented the election campaign as a choice between himself and the European Commission, and in fact it was a choice between "the euro and the drachma". Italy's initial support for the Greek new government was a strategic move aimed at drawing attention of Germany to Italy's problems and demonstrating a willingness to coordinate action with other "non-systemic" players who are taking a more critical stand with regard to measures for dealing with the eurozone crisis.

The issue of migration also led to temporary alliances. For example, after the League came

${ }^{12}$ Rome and Athens Allied against Austerity? The Finnish Institute of International Affairs. February 2015. URL: https://www.fiia.fi/wp-content/uploads/2017/01/comment7_2015eng.pdf laccessed: 07.05.2020).

13 lbid. 
to power in 2018, the notion of the "SalviniOrbán axis" began to appear in the media. The then Italian deputy prime minister met several times with the Hungarian prime minister, known for his radical position on quotas for refugees from African and Middle Eastern countries in EU member states, and he even personally inspected the wall built on the border with Serbia. Both politicians stressed they agreed on protecting national borders from the influx of immigrants, as well as on reviewing agreements with non-EU countries that do not cooperate with the integration association on repatriation of those who entered the EU territory illegally. Matteo Salvini supported Orbán's tough policy, justifying it by the need to "protect the security, the family and the Christian identity of our continent"14.

The coronavirus pandemic opened up space for new strategic alliances for Italy. Rome presented a united front with the states most affected - Spain, France, and Portugal - against the lines of Germany, Austria, the Netherlands, and Finland. Rome advocated the introduction of "coronabonds", or bonds jointly issued by eurozone member states, guaranteed by the ECB, and forming a "debt union" where tax burden would be equally distributed among citizens of the EU states, regardless of the extent to which they were affected by the pandemic. The proponents of this idea refer to it as a new Marshall Plan for Europe.

As an alternative, Berlin and its allies insisted that the countries with the greatest losses turn to the European Stability Mechanism. According to the affected countries, this would have led to a deepening economic crisis, as in Greece in the past decade. Although the consolidated position of the southern European states did not lead to the launch of coronabonds, the northern countries made concessions and agreed to create a $\$ 2$ trillion coronavirus fund, of which $\$ 209$ billion is earmarked for Italy $^{15}$. Italian Prime Minister Giuseppe Conte called the measure adequate, stating that it would "restart Italy and change its image"16.

Rome's success in finding temporary 'allies' was made possible by the image the country has developed in the international arena. Eternally balancing between the great powers and never initiating interference in the internal affairs of other states, Italy is seen as too small to offend, and at the same time too big to be offended. Membership in the leading multilateral formats allows Italy to keep in line with the major players, being considered "the smallest among the greatest," while at the same time exploiting the image of "the greatest among the smallest" when building relations with less powerful partners.

The overall positive image of the country is also supported by its cultural component, which plays the role of soft power. The cradle of European civilization, the owner of unique historical heritage and tourist destinations, the founder of opera, fashion and renowned cuisine, the producer of popular cars, and the speaker of a beautiful language: all these definitions attest to the country's attractiveness. In the last five years Italy never fell below $13^{\text {th }}$ place in the international ranking of The Soft Power 30, and the report traditionally includes "nature, architecture, lifestyle, brands and cuisine" among the strengths providing a large potential of soft power of the country ${ }^{17}$. As a result, the advantageous political neutrality, combined with a fragile economy and a rich culture, expand the country's capabilities in negotiation process, making Italy an ideal partner and mediator that does not stir up illfeeling of others.

14 Merkel Gela l'Alleanza PPE-Sovranisti. Corriere della Sera. 02.05.2019. URL: https://www. corriere.it/politica/19 maggio_02/salvini-ungheria-visita-muro-anti-migranti-felice-vedere-l-efficaciagoverno-orban-ca8ee232-6ce-4-11e9-bcbb-8ef451e0c86f.shtml (accessed: 12.05.2020).

15 Accordo sul Recovery Fund, Conte: Piano Adeguato alla Crisi. Salvini: Fregatura Grossa come una Casa. IL Sole 24 Ore. 19.07.2020. URL: https://www.ilsole24ore.com/art/vertice-ue-kurz-c-e-ancoramolta-strada-fare-ADS9GEf. (accessed: 30.08.2020).

16 Ibid.

17 The Soft Power 30. 2019 Overview. URL: https://softpower30.com/country/italy/ 〔accessed: 16.04.2021). 


\section{4}

Riccardo Alcaro, Research Coordinator at Affari Internazionali, a leading Italian international relations think tank, noted in an article written last year on Italian-American and Italian-Chinese relations in light of the pandemic that "it is widely believed among experts that one of the most important results of the coronavirus pandemic will be an increase in existing geopolitical competition, rather than international cooperation, against a backdrop of exchange of information and coordination on management of joint health systems and potentially disastrous economic consequences"18. The United States and China remain the main competitors on the global stage, whose relations, in addition to the earlier trade war, have been exacerbated by the former U.S. president's efforts to label China as the perpetrator of the Coronavirus and the global lockdown ${ }^{19,20}$. For its part, China has sent medical equipment and personnel to the most affected countries, gaining a reputation as a responsible, caring, and influential player in international relations.

European countries, being at the center of the intersection of U.S. and Chinese interests, are faced with the need to make a choice in favor of one of these powers. The example of Italy, with which China has been developing massive cooperation in recent years, is quite illustrative in this respect. The activation of bilateral ties began in the mid-2010s [Alekseenkova 2020], but during the premiership of Giuseppe Conte the Chinese agenda expanded so much that, at the behest of reformers from the Democratic Party, the press started talking about the existence of a pro-Chinese lobby in the Italian parliament ${ }^{21}$, alluding to the head of the cabinet and his closest associates. Conte's speech in the Chamber of Deputies before the vote of confidence in the government in January 2021, where the Italian prime minister spoke of the shared values and principles between China and Italy and effectively equated Beijing with Washington in Rome's foreign policy priorities, sparked particular indignation among the traditionally proAmerican right-wing forces.

Italy is the only G7 state to officially support China's Belt and Road Initiative: a bilateral memorandum of understanding and cooperation was signed in March 201922. Although there was immediate speculation in the press about Rome's estrangement from Washington, or at least a number of right-wing politicians saw signs of such a trend, the memorandum is not binding. Its signing falls within the very 'room for maneuver' granted by Washington. The proavocative rapprochement with China should be seen as another example of ad hoc alliance, aimed this time at the United States in order to regain its attention, given this partner has neglected Italy amid conflicts with Iran and North Korea, as well as domestic political problems.

During the acute phase of the coronavirus epidemic, the headlines of Italian media were filled with stories of Brussels leaving Rome to its fate ${ }^{23}$,

18 Covid, Trump Accusa la Cina: "Ha Aperto le Frontiere per Favorire la Diffusione del Virus». II Messaggero. 22.09.2020. URL: https://www.ilmessaggero.it/mondo/coronavirus_usa_cina_trump_ virus_covid_seconda_ondata_onu-5478634.html (accessed: 17.04.2021).

${ }^{19}$ Trump Accusa la Cina: "S̆ul Virus ha Fatto un Tremendo Errore». Oms e Pechino: «Nessuna Prova». Agenzia Italiana. 04.05.2020. URL: https://www.agi.it/estero/news/2020-05-04/trump-accuse-cinacoronavirus-oms-prove-8517417/ (accessed: 17.04.2021).

20 Covid, Trump Accusa la Cina: «Ha Aperto le Frontiere per Favorire la Diffusione del Virus». II Messaggero. 22.09.2020. URL: https://www.ilmessaggero.it/mondo/coronavirus_usa_cina_trump_ virus covid seconda ondata onu-5478634.html (accessed: 17.04.2021).

${ }^{21}$ Draghi: «Grazie, ci Rivedremo in Parlamento». II Premier Incaricato non Parla dei Ministri. Corriere della Sera. 08.02.2021. URL: https://www.corriere.it/politica/21_febbraio_08/draghi-grazie-cirivedremo-parlamento-premier-incaricato-non-parla-ministri-bc $\overline{6} 6991$ e-6a5a-11 eb-924b61776b6fba88.shtml. (accessed: 20.02.2021).

22 Memorandum d'Intesa tra il Governo della Repubblica Italiana il Governo della Repubblica Popolare Cinese. 23.03.2019. URL: http://www.governo.it/sites/governo.it/files/documenti/documenti/Notizieallegati/Italia-Cina 20190323/Memorandum Italia-Cina IT.pdf (accessed: 16.04.2021).

${ }^{23}$ Coronavirus, I'UE Ora Ci Prende a Schïffi. Ci Lascia senza le Mascherine. II Foglio. 06.03.2020. URL: https://www.ilgiornale.it/news/cronache/coronavirus-italia-chiede-pi-mascherine-allue-nessunoci-1836472.html. (accessed: 16.04.2021) 
member states choosing their own national interests over European solidarity, and China and Russia being the only ones who did not abandon Italy $^{24}$. Representatives of the Italian mainstream expressed their gratitude to the aid received from these countries, and "China was also included in the category of friends, despite the fact that it was the original source of the pandemic" [Maslova, Savino 2020: 46]. The issue of humanitarian aid to Italy was of geopolitical importance not only for Beijing, but for Rome as well, since the goal of returning to the focus of Washington's attention was indeed achieved: in April 2020, U.S. President Donald Trump personally pledged $\$ 100$ million in aid to Italy. Later, Secretary of State Mike Pompeo, confirming this figure, assured Italians that "no other nation will do more for you than the United States will do"25. The signing of a presidential memorandum on assistance to "one of the closest and oldest allies ravaged by the pandemic $^{\text {"26 }}$ was an indication that with the intensification of Italian-Chinese cooperation, Washington felt the need not only "to demonstrate U.S. leadership in the face of Chinese and Russian disinformation campaigns"27, but also to return Rome, which had its eye on the East, back into its sphere of influence.

The period of the fight with the pandemic was difficult for Italy, not only because of the human losses, the strain on the health care system, and the enormous economic losses, but also because of the extreme political instability. The victory of two opposition parties in the 2018 election, the year of a coalition government, and the formation of a new cabinet again headed by the nonpartisan Giuseppe Conte made the development of a foreign policy strategy situational and dependent on specific personalities in the structures of power.

Arguing on all points of the political agenda, the coalition partners of the League and the Five Star Movement were not united on the issue of enhancing cooperation with China. While the then Minister of Economic Development Luigi Di Maio claimed that the memorandum on the Belt and Road initiative offered "many opportunities for Italian SMEs to work in China, which means spreading 'Made in Italy' products around the world"28, the Italian Minister of the then Interior Matteo Salvini stated that he would "say a firm 'no' if any Chinese acquisition would threaten Italian national security"29. He added that any investment in strategic sectors requires the utmost caution, and "if we were talking about Americans, it would be a different matter". Di Maio also stressed that "we are not talking about a new geopolitical alliance" ${ }^{30}$ between Italy and China.

In other words, it was not a matter of of replacing Washington with Beijing, but the Italians used the ostensible rapprochement with the main rival of its main ally quite skillfully - in a sense, it was political blackmail - as a foreign policy tool. The increased attention to Italy's problems on the part of the U.S. administration proves the effectiveness of this tool.

$$
* * *
$$

In the post-bipolar era, accommodationism - which is expressed in the avoidance of armed conflicts, the preference for diplomatic

\footnotetext{
${ }^{24}$ Dai Paesi UE Nessun Sostegno Medico, Solo la Cina Ci Ha Aiutato. Europa Today. 11.03.2020. URL: https://europa.today.it/attualita/coronavirus-cina-ue-mascherine.html (accessed: 16.04.2021).

${ }_{25}$ Coronavirus, Intervista a Mike Pompeo. Corriere della Sera. 09.04.2020. URL: https://www. corriere.it/esteri/20_aprile_09/coronavirus-intervista-mike-pompeo-per-l-italia-siamo-quelli-che-fannofaranno-piu-collaboriamo-la-cina-ma-esigiamo-trasparenza-2389cfa6-79c7-11ea-afb4-c5f49a569528. shtml. (accessed: 20.08.2020).

${ }^{26}$ Memorandum on Providing COVID-19 Assistance to the Italian Republic. White House. URL: https:// www.whitehouse.gov/presidential-actions/memorandum-providing-covid-19-assistance-italian-republic/ (accessed: 31.08.2020).

27 Ibid.

28 Via della Seta. Di Maio e Salvini Divisi sul Memorandum d'Intesa tra Italia e Cina. Avvenire. 14.04.2019. URL: https://www.avvenire.it/attualita/pagine/via-della-seta-per-salvini-non-e-un-dogmaper-di-maio-s-ha-da-fare. (accessed: 06.06.2020).

29 Ibid.

30 lbid.
} 
ways to resolve international conflicts, and the passive fulfillment of allied obligations within NATO and other international organizations with absolute loyalty to Washington - remains an integral part of national strategic culture and the main behavioral pattern of Italy. Autonomy in foreign policy is available only within the limits that do not undermine the strength of the established Rome-Washington axis. Italy is capable of using ad hoc alliances for foreign policy blackmail; participation in such alliances allows it to increase its value in the eyes of its partners and maintain influence in the international arena.

\section{References}

Alekseenkova E.S. (2020). Diskursivnaia sila KNR protiv normativnoi sily ES: kazus Italii. [PRC Discoursive Force Against the Normative Force of the EU: The Case of Italy]. Mirovaia ekonomika i mezhdunarodnye otnosheniia. Vol. 64. No. 5. pp. 62-72.

Bogaturov A.D. (ed.) (2010). Sovremennaya mirovaya politika. Prikladnoj analiz [Contemporary World Politics. Applied Analysis]. Moscow: Aspekt Press.

Castronovo V. (1999). Fiat, 1899-1999: Un Secolo di Storia. Rizzoli.

Croci 0. (2008). Not a Zero-Sum Game: Atlanticism and Europeanism in Italian Foreign Policy. The International Spectator. Vol. 34. No. 4. pp. 137-155.

Croci 0. (2015). All Quiet on the Western Front. Italy and Transatlantic Relations. In: L. Marchi, R. Whitman (eds.). Italy's Foreign Policy in the Twenty First Century: A Contested Nature? London: Routledge.

Diodato E., Niglia, F. (2017). Italy in International Relations. The Foreign Policy Conundrum. Palgrave Macmillan.

Holsti K. (1976). The Study of Diplomacy. In: J.N. Rosenau, K.W. Thompson, G. Bond (eds.J. World Politics. New York: Free Press. P. 293-311.

Jordan J., Stulberg A. \& Troitskiy M. (2021a). Statecraft in U.S.-Russia Relations: Meaning, Dilemmas, and Significance. Mezhdunarodnye protsessy. Vol. 19. No. 1e. P. 4-17.

Jordan J., Stulberg A. \& Troitskiy M. (2021b). Statecraft in U.S.-Russia Relations: Meaning, Dilemmas, and Significance. Mezhdunarodnye protsessy. Vol. 19. No. 1r. P. 6-25.

Istomin I.A, Baikov A.A. (2019). Dinamika mezhdunarodnykh al'iansov v neravnovesnoi mirovoi sisteme. [Dynamics of International Alliances in an Unbalanced World Structure]. Mirovaia ekonomika $i$ mezhdunarodnye otnosheniia. Vol. 63. No. 1. pp. 34-48.

Istomin I.A. (2018). Logika povedeniia gosudarstv v mezhdunarodnoi politike [Logics of States' Behaviour in International Politics]. Moscow: Aspekt Press.

Khrustalev M.A. (2011). Metodologiia prikladnogo politicheskogo analiza [Methodology of Applied Political Analysis]. Moscow: Prospekt.

Manta F. (2018). La Diplomazia Economica Come Strumento delle Relazioni Internazionali: I'Esempio Mattei e il Marchio "Fiat". Eunomia. Rivista semestrale di Storia e Politica Internazionali. No. 1. pp. 197-208.

Maslova, E.A. (2016). Evropeizm i atlantizm vo vneshnei politike Italii [Italian Foreign Policy between Atlanticism and Eurocentrism]. Mezhdunarodnye protsessy. Vol. 14. No. 4. pp. 106-115.

Maslova E.A., Savino G. (2020). Pandemiia po-ital'ianski: stress-test dlya politicheskoi sistemy [Pandemic all'italiana: stress-test for the political system]. Sovremennaia Evropa. No. 4. pp. 37-49.

Nuti L. (2011). Italian Foreign Policy in the Cold War. A Constant Search for Status. In: M. Carbone (ed.). Italy in the Post-Cold War Order: Adaptation, Bipartisanship and Visibility. Lanham: Lexington Books. P. 25-45.

Rosa, P. (2014). The Accommodationist State: Strategic Culture and Italy's Military Behaviour. International Relations. Vol. 28. No. 1. pp. 88-115.

Salacone A. (2013). Le Relazioni Italo-Sovietiche nel Decennio 1958-1968: Uno Sguardo da Mosca. Storicamente. No. 9. URL: https://storicamente.org/sites/default/images/articles/media/1757/ salacone.pdf (accessed: 10.04.2021)

Salacone A. (2014). SSSR i «neo-atlanticheskaia» Italiia v 1960-e gg. [The USSR and and the "NeoAtlantic" Italy in the 1960-s]. The Italian Republic in a Changing World. Reports of the Institute of Europe. No. 306. pp. 110-122.

Salacone A. (2018). Energeticheskaia politika SSSR kak faktor vliianiia na Italiiu v 1960-kh godakh [Energy Policy of the USSR as a factor of the Influence on the Italy in 1960s]. Sovremennaia Evropa. No. 6. pp. 134-141.

Shakleina T.A. (ed.) (2014). Vvedenie v prikladnoi analiz mezhdunarodnykh situatsii [Introduction to applied analysis of international situations]. Moscow: Aspekt Press. 288 p. 
Shibkova M., Maslova E., Loreto R. (2019). Evolution of the Russian President V. V. Putin's Image in the Opinion of the Italian Citizens [Evoliutsiia obraza Prezidenta Rossii V.V. Putina v glazakh ital'ianskikh grazhdan]. Izvestia of the Ural Federal University. Series 3 - Social Sciences. Vol. 14. No. 1. pp. 140-153.

Zonova T.V. (2019). Elections of 2019: Eurooptimists vs Eurosceptics [Vybory 2019 goda: evrooptimisty protiv evroskeptikov]. Sovremennaia Evropa. No. 3. pp. 62-69.

\title{
АЛЬЯНСЬ AD HDC КАК ДОМИНАНТА ВНЕШНЕПОЛИТИЧЕСКОГО ИНСТРУМЕНТАРИЯ ИТАЛИИ
}

\author{
МАРИЯ ШИБКОВА \\ МГИМО МИД России, Москва, Россия
}

\section{Резюме}

На протяжении всего послевоенного периода Италия, несмотря на экономические проблемы и политическую нестабильность, оставалась ключевым игроком ЕС, членом «группы двадцати» и «группы семи», что наделяло её статусом великой державы. Не имея глобальных амбиций, Италия выступала влиятельным субъектом международных отношений благодаря аккомодационизму как основному поведенческому паттерну, а также инструментальному использованию ad hос альянсов - прагматического подхода, делающего политику страны гибкой и непредсказуемой. Слишком мала для того, чтобы представлять опасность, но при этом достаточно велика, чтобы бояться самой, Италия не вызывала раздражения потенциальных партнёров, что сделало её универсальным союзником как в Европейском Союзе, так и за его пределами. Сотрудничая с Грецией в борьбе за отмену мер жёсткой экономии, с Испанией и Францией по вопросу введения коронабондов, с Венгрией по миграционной проблеме, Италия повысила свою значимость в глазах Парижа, Берлина и Брюсселя, нуждающихся в ней для обеспечения безопасности и солидарности. Стратегическое партнёрство с США - константа внешней политики Италии - позволяет последней чувствовать себя уверенно на международной арене. Один из наиболее преданных союзников Вашингтона, Рим предпочитает двигаться в фарватере его политики, даже когда это противоречит позиции географически более близких партнёров по Евросоюзу. Высокая степень лояльности позволяет Италии сохранять «свободу манёвра» во внешнеполитических вопросах настолько, насколько это не ставит под угрозу прочность оси Рим-Вашингтон. Тем не менее национализм администрации США Джозефа Байдена заставил Италию применить ad hoc альянс уже против Вашингтона, выбрав во временные союзники Пекин, сотрудничество с которым активно развивается на фоне участия Италии в инициативе «Пояса и пути», а также гуманитарного сотрудничества в борьбе с пандемией.

\section{Ключевье слова:}

внешняя политика Италии; инструментарий внешней политики; коронавирус; коронакризис; российско-итальянские отношения; отношения ЕС-Италия; итальянско-американские отношения; итальянско-китайские отношения. 